\title{
Passwords
}

Volume 13 | Issue 1

Article 17

$12-20-2012$

\section{In the Garden}

Dan Skubi

dcs22011@mymail.pomona.edu

Follow this and additional works at: http://scholarship.claremont.edu/passwords

Part of the Art and Design Commons, Creative Writing Commons, and the Photography Commons

\section{Recommended Citation}

Skubi, Dan (2012) "In the Garden," Passwords: Vol. 13: Iss. 1, Article 17. DOI: 10.5642/passwrd.20121301.17

Available at: http://scholarship.claremont.edu/passwords/vol13/iss1/17

This Poetry is brought to you for free and open access by the Journals at Claremont at Scholarship @ Claremont. It has been accepted for inclusion in

Passwords by an authorized administrator of Scholarship@ Claremont. For more information, please contact scholarship@cuc.claremont.edu. 


\section{In the Garden}

\section{Dan Skubi}

When I find myself in times of trouble, my mind often turns to contemplate you.

In the dark moonless nights, in the winter of my discontent and in the long quotidian hours, I find transcendence in the study of your sublime beauty; in the merry-solemn motion of your face, in your rich-hued eyes, in the perfect angle of your knee when you sit, in the strata of your hair and in the smooth mathematical curve of your neck. That Edenic innocence that trips laughing from your tongue and lends grace to your motion, compels an old apostate to bend knee again and do homage.

You are hymn, prayer, and goddess all in one, and for your sake I might fall into faith again. If I were allowed, I would build a temple in your bed; work sacred oil through your hair and baptize myself in you.

I would like to plant a kiss in the hollow of your jaw and watch it grow, spreading its tendrils downward across your skin and making a garden of your body for my serpent self to slither through in search of forbidden fruit. 